\title{
As novas configurações do tempo e do espaço e seus efeitos para o labor jornalístico
}

\section{The new configurations of time and space and their impact on the journalistic labor}

\section{Jeana Laura da Cunha Santos}

Mestre e Doutora em Literatura e Pós-Doutora em Antropologia Social pela Universidade Federal de Santa Catarina (UFSC). <jeanasantos@terra.com.br>

\section{RESUMO}

\begin{abstract}
Este trabalho analisa três passagens no espaço efetuadas pelo jornalista em diferentes tempos com o objetivo de refletir sobre a precarização da atividade profissional na atualidade. A primeira passagem remonta ao passado para investigar a saída do litera todo espaço da casa para a rua, prefigurando o surgimento do jornalista. A segunda traz à luz a formação dos primeiros gabinetes, numa transposição do espaço da rua para o espaço de trabalho. E a terceira sugere que os problemas da metrópole moderna e os novos fluxos comunicacionais desalojam o jornalista da rua ou do gabinete para trazê-lo novamente para casa, não sem prejuízo para sua saúde. Como protocolo metodológico, utiliza uma pesquisa de natureza teórica que abarca a História do Jornalismo, a Filosofia e a Sociologia. Espera-se que contribua para ampliar os fundamentos teóricos e epistemológicos do Jornalismo e permita refletir sobre a prática, a saúde e a vida mental do jornalista.
\end{abstract}

Palavras-chave: Comunicação. História do Jornalismo. Trabalho.

\begin{abstract}
This paper examines three transitions in space concerning the labor of the journalists over time as it seeks to reflect on the current deterioration of their professional work conditions. In the first transition, we look to the past to analyze the moment when writers left their houses to venture the space of the streets, prefiguring the emergence of the journalist. In the second, we delineate the appearance of the first offices as the writers moved from the street space to the work space. In the third, we analyze the extent to what the problems of the modern metropolis and its communicational fluxes push the journalists back into their houses compromising their health in the process. This paper purposes a theoretical approach, regarding the history of Journalism, Sociology and Philosophy studies. We seek to reflect on the deterioration of the current work conditions of the journalists by looking into their pioneer urban experiences. We intend to contribute to the theoretical and epistemological debates of the journalism and to reflect on their practice and their mental and physical health.
\end{abstract}

Keywords: Communication. History of the Journalism. Work

\section{Introdução}

Havia um tempo em que, ao transpor os limites da casa burguesa para viver a experiência das ruas, o sujeito urbano desperdiçava o tempo para ganhar o espaço. Numa época de informação virtual, em rede, economiza-se o tempo, encurtam-se seus átimos, a fim de se ganhar mais espaço.

Havia um tempo em que se perder na multidão, na massa da grande cidade, correspondia a um exercício de ocultamento para perscrutar os tipos urbanos, perfilando-os tal e qual detetive que nunca é visto enquanto olha. Para 
isso, existiam, os flâneurs e os fisiologistas de Paris, especialistas em vagar pela cidade para perfilar os tipos urbanos, estrangeiros oriundos da vida doméstica e privada da casa para compor o cenário público e aberto da cidade e que seriam objeto de análise de Walter Benjamin (1994a) no livro que escreveu sobre o poeta Charles Baudelaire.

Em tempos de projeção da imagem, o livro do rosto (Facebook) e outros derivativos das redes sociais expõem quem vê e quem olha e o perfilado não é mais o outro, mas o próprio sujeito, que se exibeem fotos de si mesmo (selfies). Seo objetivo do flâneur era observar o outro, ocultando-se no anonimato da multidão, hoje o Facebook, em sua máxima exigência de que "tudo seja social", elimina o que tornava possível o flanar: a solidão, o anonimato, o mistério, a observação à distância. Tal sistema de compartilhamento de tudo nos impede de sermos indiferentes. Não estar em uma rede social remove-nos dos acontecimentos que já não se processam mais no palco da cidade, mas na sua versão virtual, no espaço da tela, onde tudo acontece porque pouca coisa acontece de relevante, onde todos aparentam ser o que muitas vezes não são. As relações são íntimas porque não gozam da intimidade real e ambivalente próprias das relações humanas. Morozov (2012) argumenta que no "compartilhamento sem atrito" do Facebook, deve-se preocupar só com o que não se quer compartilhar, porque tudo o mais será compartilhado automaticamente.

Nestes desvios do privado ao público, do espaço da casa para o espaço da rua, a prefiguração do jornalista já estava imbricada até a raiz. Primeiro com o fisiologista parisiense, que daria lugar ao flâneur, cujo apogeu encontrou em Baudelaire sua máxima expressão. Já no contexto brasileiro da virada do século XIX para o XX, com o cronista, prefiguração do jornalista, cuja roupagem serviu tão bem a João do Rio, este Baudelaire dos trópicos, talvez o primeiro repórter brasileiro a submergir na cidade, documentando as ruas, os tipos, as pequenas profissões ignoradas, os becos e o submundo, perdendo-se no meio da massa para dali extrair suas reportagens, até hoje atuais.

Havia um tempo em que era necessário ao jornalista movimentar-se pela cidade no ritmo da tartaruga. Como nos lembra Benjamin (1994a), o flâneur levava este animal de estimação para passear no intuito de se contrapor ao ritmo ditado pelo industrialismo iminente. Ocupar então o espaço significava fazê-lo de forma lenta. Dominar a cidade era entendê-la em seus traços enviesados, em suas esquinas abruptas, em seus meios de transporte cada vez mais acelerados, em sua fauna de tipos, dos anódinos aos excêntricos.

Hoje a cidade desaloja o jornalista, empurra-o para dentro do gabinete ou para os espaços intermediários e seguros dos cafés. Não mais os cafés cujas mesas 
eram colocadas no bojo das ruas ou das galerias, mas aqueles estabelecimentos franqueados que ficam abrigados nos corredores dos shoppings-centers.

Ligando estas duas pontas temporais do labor jornalístico, o presente artigo se propõe a analisar o quanto a urgência do tempo provocou uma crise no espaço. Hoje, a atual configuração do trabalho jornalístico a partir de uma lógica de fluxo, de rede, de velocidade, leva o profissional a sentir cada vez mais no corpo e na vida mental a angústia de não mais pertencer ao espaço e de não poder acompanhar o ritmo veloz do tempo. Pede-se a ele cada vez mais e mais velocidade:

\footnotetext{
Não é mais o tempo de passagem que serve de padrão para o espaço percorrido, mas sim a velocidade, a distância-velocidade, que tornouse a medida, a dimensão privilegiada tanto do espaço quanto do tempo (Virilio, 1993, p. 44).
}

Este trabalho, que parte de uma reflexão híbrida e transdisciplinar formulada a partir de revisão bibliográfica que abarca o campo da história do Jornalismo, iluminada por teorias da Literatura, da Sociologia e da Filosofia, propõe analisar o quanto a nova configuração do espaço, em diferentes tempos, condiciona uma nova morfologia do trabalho jornalístico. Para tanto, propõe três deslocamentos espaciais que são alegóricos do processo de formação da atividade profissional, do seu entusiasmo pioneiro ao posterior desencantamento atual.

A primeira passagem (da casa à rua) alude à formação dos primeiros jornalistas a desabitar a casa para ocupar a cidade no intuito de domesticá-la.

A segunda passagem (da casa ao escritório) resgata a formação do gabinete de trabalho/redação como o princípio da desocupação da cidade.

E a terceira passagem (da rua e do escritório a casa), investiga o quanto o ciberespaço, praticado em todos os espaços e, portanto, em espaço algum, volatiza o aparelho sensório do jornalista, repercutindo em seu corpo e desalojando-o tanto da casa quanto da rua. Neste não lugar, neste home-office, que não é nem casa (home) e nem tampouco escritório (office), o jornalista economiza o tempo do deslocamento para dilatar o tempo do trabalho. E assim, na busca pela ubiquidade do tempo instantâneo das informações em tempo real, o jornalista contemporâneo perde também o espaço. Conforme Bauman (1998, p. 113), "uma vez disfarçado e não mais um vetor, não mais uma seta com um indicador, ou um fluxo com uma direção, o tempo já não estrutura o espaço". 
Além de perder tais vetores, perde também a saúde. São muitos os relatos de que o exercício diário da profissão estaria levando os jornalistas às mais variadas doenças, ao sofrimento, à angústia, ao estresse e, pior cenário, ao silêncio sobre sua condição, o que potencializaria ainda mais o martírio.

O objetivo deste trabalho é, então, investigar o quanto a aceleração do tempo e a desestruturação do espaço no labor jornalístico estariam afetando a saúde do jornalista contemporâneo. Além da pesquisa histórica, utiliza como protocolo metodológico entrevistas semiestruturadas realizadas com profissionais que fazem uso do sistema de home-office ou do espaço semipúblico dos cafés ou shoppings para exercer seu ofício.

Da análise efetuada, sobretudo fundamentada em documentação, entrevista e em pesquisa histórica e sociológica, é possível recompor a existência de três passagens significativas que marcaram (e ainda marcam) modos de vida e expressões da profissão de jornalista, o de ontem e o de hoje; o que ainda percorre a rua ou o que se recolhe a casa.

\section{Primeira passagem: da casa à rua}

O espaço da casa, com seus contornos familiares, muros, portas, umbrais, abriga o sujeito dos perigos da rua. Segundo Duby (2009), o verbo privar (domar, domesticar) significa extrair do domínio selvagem e transportar para um espaço protegido, seguro, tal qual uma fortaleza sitiada. Esse lugar é o espaço familiar da casa.

Para Bachelard (1988, p. 26), "a casa afasta contingências, multiplica seus conselhos de continuidade. Sem ela, o homem seria um ser disperso. [...] A vida começa bem, começa fechada, protegida, agasalhada no regaço da casa".

Também Freud (1974) considera a casa para moradia um lugar seguro, substituto do útero materno, para o qual possivelmente todo homem anseia em retornar.

Mas a modernidade traria consigo um princípio de inquietação, de malestar, que desalojaria o indivíduo da casa burguesa empurrando-o para a rua'. Segundo Morin (1977, p. 111), de ilhota de harmonia, "pequeno paraíso de conforto, de bem-estar, de status, lindamente decorado e arrumado", a casa torna-se também a sede de uma crise emergente, onde nos deparamos com aquele com o qual não sabemos mais conviver: nós mesmos.

Porém, este desalojamento da casa seria vivido com certa resistência. Conforme Benjamin (1994a), a burguesia se empenharia em buscar uma

1 No artigo "Narrativas sobre a cidade: entre o medo e o fascínio" (Santos, 2014), publicado recentemente na revista Comunicação, Mídia e Consumo, discuto a questão, aqui retomada, do medo e do fascínio que a cidade exercia nos nossos primeiros escribas. 
compensação pelo desaparecimento dos vestígios da vida privada na cidade grande, apropriando-se cada vez mais de seus artigos e acessórios caseiros (capas e estojos para chinelos e relógios de bolso, para termômetros, talheres e guarda-chuvas etc.), fixando sua marca nos objetos, enfeitando-os, cobrindo-os, tornando a casa um reduto apropriado contra a ameaça da perda de identidade.

Além deste apego às coisas da casa, a rua também era entendida como uma ameaça. Se a vida privada é, segundo Duby (2009), uma vida de família e, portanto, fundada na confiança mútua, o espaço da rua era visto como um domínio selvagem, estrangeiro. Se ao privado pertencem os seres e as coisas abrigados no círculo da família, a rua pertence ao domínio dos não familiares, dos estranhos. E, portanto, um lugar em que a desconfiança deveria prevalecer.

Fora para diminuir este estranhamento em relação ao espaço da rua e à multidão de estranhos que por ela vagavam que teria surgido na Paris do começo do século XIX, segundo Benjamin (1994a), a figura do fisiologista. Este tipo tinha por ofício aplacar o medo que as pessoas tinham da cidade descrevendo a primeira literatura sobre as ruas e os tipos que nela habitavam: a "panorâmica". Dentro deste gênero, havia os fascículos em formato de bolso chamados de "fisiologias", que se ocupavam da descrição de tipos humanos que circulavam nas feiras de Paris. Mais tarde, dedicar-se-iam à consagração da cidade, perfilando suas ruas, seus panoramas, tudo para tornar aprazível a ameaça do outro estranho e do espaço "estrangeiro".

No contexto brasileiro, um dos maiores fisiologistas foi sem dúvida o escritor João do Rio que não só documentava os vários tipos que habitavam o espaço urbano (o cigano, o trapeiro, o apanha-rótulos, o selista, o caçador, o ledor, o tatuador, o vendedor de orações, o mercador de livro, o pintor da cidade, o velho cocheiro), como a própria rua se convertia num personagem. Para além de ser "apenas um alinhado de fachadas por onde se anda nas povoações", considerava-a muito mais do que isso: "Ora a rua é mais do que isso, a rua é um fator da vida nas cidades, a rua tem alma!" (João do Rio, 2011, p. 29).

A mesma alma é aludida por Benjamin quando descreve a experiência do frequentador da rua:

Uma embriaguez acomete aquele que longamente vagou sem rumo pelas ruas. A cada passo, o andar ganha uma potência crescente; sempre menor se torna a sedução das lojas, dos bistrôs, das mulheres sorridentes, e sempre mais irresistíveis o magnetismo da próxima esquina, de uma massa de folhas distantes, de um nome de rua (Benjamin, 1994a, p. 186). 
Benjamin descreve no excerto o flâneur, mas poderia estar descrevendo sem dúvida um jornalista do começo do século XX. Aliás, ele mesmo trata de aproximá-los: "A base social da flânerie é o jornalismo. É como flâneur que o literato se dirige ao mercado para se vender" (Benjamin, 1994a, p. 225). Curioso constatar que João do Rio, muito antes de Benjamin, já faria alusão ao flâneur (esse "pedestre da poesia da observação") para explicar sua relação de amor às ruas. "Eu fui um pouco esse tipo complexo, e, talvez por isso, cada rua é para mim um ser vivo e imóvel" (João do Rio, 2011, p. 33). Afinal, segundo ele,

Para compreender a psicologia da rua não basta gozar-lhe as delícias como se goza o calor do sol e o lirismo do luar. É preciso ter espírito vagabundo, cheio de curiosidades malsãs e os nervos com um perpétuo desejo incompreensível, é preciso ser aquele que chamamos flâneur e praticar o mais interessante dos esportes - a arte de flanar (João do Rio, 2011, p. 31).

Esporte esse praticado também pelo personagem Isaías Caminha, do primeiro livro do escritor Lima Barreto, publicado em 1909, um ano depois da crônica de João do Rio:

[...] quando desci à rua, ainda brilhava em frente à Prefeitura um combustor de gás. O ambiente não era de luz nem de treva - era uma penumbra algodoada e nevoenta com que começam certas manhãs no Rio de Janeiro. Os raros transeuntes moviam-se esbatidos naquela ambivalência indecisa. Andei. Ao chegar à Rua do Ouvidor, a rua dos lentos passeios elegantes, havia uma agitação de mercado. Cestos de verduras, de peixes, de carnes, passavam à cabeça de mulheres e homens; os quitandeiros ambulantes corriam por ela acima; pequenas carroças de hotéis caros davam-se ao luxo de atravessá-la em toda a extensão; e pelas soleiras das portas imensas moles de jornais diários eram subdividos pelos vendedores de todos os pontos da cidade (Barreto, 2001, p. 68-69).

Aliás, conforme Needell (1993), a Rua do Ouvidor converte-se num símbolo da imitação do estilo de vida que se tinha nos bulevares europeus, com seus passeios diários, os chás nas confeitarias elegantes e uma vestimenta copiada dos últimos modelos de Paris e Londres. Com a vinda da corte portuguesa para o Rio e a imigração dos primeiros colonos franceses, tornara-se um lugar onde 
florescia o comércio das modas e onde os melhores hotéis, cafés e confeitarias se instalariam. Seria nela que também Machado de Assis ${ }^{2}$ extrairia os assuntos para as suas crônicas, além da própria rua em si ser um tema constante. “Naturalmente, cansadas as pernas, meto-me no primeiro bonde, que pode trazer-me a casa ou à Rua do Ouvidor, que é onde todos moramos", escreveria ele em crônica de 1889, compilada por Gledson (1996). Ali, "onde a vida passa um burburinho de todos os dias e de cada hora. Chovem assuntos modernos" (Gledson, 1996, p. 190). Assim descrevera a capacidade de tal rua de produzir notícias:

\begin{abstract}
Para os que as buscam por todos os recantos da cidade, deve ter sido uma semana trapalhona; para mim, que não as procuro fora da Rua do Ouvidor, a semana foi interessante e plácida. Pode ser que erre; mas ninguém me há de ver pedir notícias em outras ruas. Às vezes perco uma verdade da Rua da Quitanda por uma invenção da Rua do Ouvidor; mas há nesta rua um cunho de boa roda, que dá mais brilho ao exato, e faz parecer exato o inventado. Acresce a qualidade de pasmatório. As ruas de simples passagem não têm graça nem excitam o desejo de saber se há alguma coisa. O pasmatório obriga ao cotejo. Enquanto um grupo nos dá uma notícia, outro, ao lado, repete a notícia contrária; a gente coteja as duas e aceita uma terceira (Gledson, 1996, p. 242-244).
\end{abstract}

Como se vê, o fascínio da rua instigava nossos primeiros jornalistas, convidava-os a uma vida de aventuras e de registro dos assuntos modernos por ela produzidos: a expressão da velocidade, a exposição da vida privada, as modas, os costumes, as notícias, o progresso. Era na rua que os tempos modernos se encenavam na novidade dos transportes públicos, no treinamento da fragmentação de um olhar que precisava estar apto para os choques da vida moderna, na domesticação do vizinho ameaçador coabitante do mesmo espaço, na descoberta da caminhada pelas vias públicas, onde vez por outro o pedestre interrompia o passo para contemplar a multidão a partir de um café. Tal qual um flâneur para o qual

[...] os letreiros esmaltados e brilhantes das firmas são um adorno de parede tão bom quanto a pintura a óleo no salão do burguês; muros são a escrivaninha onde apoia o bloco de apontamentos; bancas de

2 Recupero aqui pesquisas realizadas para minha tese de doutorado intitulada "Experiências pioneiras de Machado de Assis sobre o jornal", defendida em 2002, na qual analiso a faceta jornalística do escritor carioca em suas primeiras incursões pela cidade por intermédio da crônica (Santos, 2002). 
jornais são suas bibliotecas, e os terraços dos cafés, as sacadas de onde, após o trabalho, observa o ambiente (Benjamin, 1994a, p. 35).

\section{Segunda passagem: da rua ao escritório}

Mas se o flâneur usava o muro como escrivaninha, a profissionalização do jornalista iria tirá-lo tanto da casa quanto da rua para a funcionalidade de outra escrivaninha: a do escritório. Precisamente o termo escritório (do latim scriptorin) tem sua origem etimológica a partir deste mobiliário típico encontrado nos gabinetes: a escrivaninha. Por essa razão, as atividades desenvolvidas nestes ambientes (leitura, escrita, contabilidade, cálculo, projeto etc.) foram também denominadas "atividades de gabinete".

Traçando um panorama da história do escritório, poderemos usá-lo como metáfora da transposição do livro ao jornal e do literato ao jornalista. Tal qual o surgimento dos primeiros livros, durante a Idade Média os scriptoriums costumavam ser encontrados em mosteiros. $\mathrm{O}$ aparecimento das indústrias, a partir de meados de 1860 , demandou uma necessidade por espaços para a realização de atividades administrativas de controle da produção. Assim como os primeiros escribas, literatos ou jornalistas incipientes usavam os gabinetes de suas casas para exercer o ofício, empresários acabaram construindo suas residências sobre a loja ou fábrica de sua propriedade, e os afazeres de seus funcionários, que muitas vezes acabavam residindo, no mesmo local, se confundiam com os afazeres domésticos. Tal qual o flâneur benjaminiano que, como vimos, converte os muros em escrivaninha onde apoia o bloco de apontamentos, os cafés também seriam utilizados por empresários pioneiros para a realização de reuniões importantes de trabalho.

Porém, o aumento da população de funcionários (copistas, contadores, bancários, advogados etc) levaria tais empresários a procurar espaços maiores para abrigá-los e já no final do século XIX surgem os primeiros escritórios comerciais nas cidades industriais dos Estados Unidos ${ }^{3}$.

À parte as diferenças entre os países e continentes, esse momento coincide com o percurso histórico de afirmação profissional dos jornalistas, que ocorreria na segunda metade do século XIX e nas primeiras décadas do século XX. Com a industrialização da imprensa - que passa de "uma actividade artesanal, amadora e irregular" para uma "actividade regular, permanente, com grande força no mercado e forte influência na sociedade" -, criam-se empresas,

3 Conforme o artigo "Escritório: história de produtividade, desconforto e poder", da Revista Você S/A de 26 de jun. 2014, no ano de 1860 os Estados Unidos contavam com 750 mil pessoas trabalhando em escritórios. Em 1910, o número saltou para mais de 4 milhões (Tozzi, 2014). 
cresce um mercado de trabalho e formam-se redações estabilizadas (Fidalgo, 2007). E assim, se o jornalista, tal qual flâneur ou fisiologista, migrou do espaço domesticado da casa para se aventurar na rua, transformando os cafés num ambiente fértil de trabalho, houve um momento em que a profissionalização da profissão levou-o de volta ao gabinete. Não ao gabinete acolhedor da casa, onde os objetos pessoais residem em sua calma e imobilidade, mas ao escritório da redação, cuja disposição dos móveis e arquitetura do lugar iriam refletir o aspecto hierárquico e paternalista que se estabelecia, e a velocidade das rotativas iria ditar o ritmo no qual o jornalista deveria deslizar a pena sobre o papel da agora produção em série. Escritório esse cujo dono do negócio, ou um intermediário seu na figura do supervisor, postado numa sala individual no nível superior ou num mezanino, controlava os funcionários e comunicava sua hierarquia. "A sala do chefe está eriçada de armas. Aquilo que, tomado como conforto, alicia quem entra, é na verdade um arsenal dissimulado. Um telefone sobre a escrivaninha toca a todo instante" (Benjamin, 1994b, p. 55).

Assim, conforme Fonseca (2004), no final do século XIX e início do XX, esse escritório de layout taylorista preconizava a segregação espacial como meio de reafirmar as diferenças hierárquicas, visando o incentivo da competição interna e o estímulo das performances individuais. A racionalização introduzida pela padronização do mobiliário e a rigidez do layout era uma forma de assegurar a disciplina e a linearidade do processo de trabalho. Esse novo tipo de escritório, apesar de fisicamente separado da fábrica, apresentava uma organização espacial que lembrava a planta industrial: um grande salão central era destinado aos funcionários dos escalões inferiores (datilógrafos, estenógrafos, contadores, contínuos, etc), onde as mesas eram dispostas em fileiras paralelas, numa mesma direção, sob as vistas de um supervisor instalado defronte. Ao redor desse grande salão central, localizavam-se as salas privativas dos gerentes, que eram delimitadas por divisórias envidraçadas. Os funcionários dos escalões mais altos ocupavam os pavimentos superiores e nesses, suas salas confortáveis e privativas, revestidas com acabamentos internos de qualidade, situavam-se nos pontos com melhor vista e insolação (Fonseca, 2004).

Se essa era a organização do espaço de trabalho da maioria das empresas da época, não seria diferente com a "fábrica de notícias". Lima Barreto (2001), no livro já citado "Recordações do escrivão Isaías Caminha", documentaria os bastidores da imprensa brasileira na virada para o século XX e, de quebra, detalharia a sala da redação de um jornal do período. 


\begin{abstract}
Era uma sala pequena, mais comprida que larga, com duas filas paralelas de minúsculas mesas, em que se sentavam os redatores e repórteres, escrevendo em mangas de camisa. Pairava no ar um forte cheiro de tabaco; os bicos de gás queimavam baixo e eram muitos. $O$ espaço era diminuto, acanhado, e bastava que um redator arrastasse um pouco a cadeira para esbarrar na mesa de trás, do vizinho. Um tabique separava o gabinete do diretor, onde trabalhavam o secretário e o redator-chefe; era também uma superfície diminuta, mas duas janelas para a rua davam-Ihe ar, desafogavam-no muito (Barreto, 2001, p. 83-84).
\end{abstract}

Como se vê pela descrição de Lima Barreto, e como sempre ocorre em todos os momentos de transição, duas formas conviviam lado a lado antes que uma suplantasse a outra em definitivo: o redator encarregado de escrever a notícia e o repórter que se limitava a obtê-las pelas ruas da cidade. Para esse último, o escritório era apenas uma parada, uma estação, na flânerie incessante pelo espaço urbano que ainda o seduziria por algum tempo. Afinal, como diria Machado de Assis em uma de suas crônicas compiladas por Coutinho (1959), "um historiador de quinzena, que passa os dias no fundo de um gabinete escuro e solitário, que não vai às touradas, às câmaras, à Rua do Ouvidor, um historiador assim é um puro contador de histórias" (Coutinho, 1959, p. 361).

\title{
Terceira passagem: da rua e do escritório a casa
}

Se para Machado de Assis o mais importante era ir às ruas buscar as notícias que a cidade oferecia em profusão, pede-se ao jornalista contemporâneo muito mais. Exige-sedele que desempenhesimultaneamente trabalhos dereportagem, redação, edição, documentação, design, fotografia. Conforme Salaverría e Negredo (2008), esta acumulação de tarefas não é nova. Vem ocorrendo há pelo menos meio século, quando os repórteres de rua se converteram em redatores de mesa. Soma-se a isso, conforme Salaverría (2006), o fato de os jornalistas terem de aprender as peculiaridades de uma nova plataforma de difusão (a rede) e, ao mesmo tempo, responder as demandas de um público cada vez mais exigente e participativo.

Não só a polivalência ${ }^{4}$, com sua economia de custos e de tempo, exigida pelas modernas redações estariam removendo os jornalistas do espaço da

4 Para os autores, a polivalência é funcional e midiática. A funcional se produz quando o redator de antes passa a assumir tarefas distintas das de sua especialidade. A polivalência midiática se produz quando um jornalista cobre uma informação para distintos meios (impressos, radiofônicos, televisivos, de Internet) de um mesmo grupo jornalístico. 
cidade. Hoje, é a própria cidade que entra em colapso. Os transportes públicos desalojam o pedestre, o rápido relance dos olhos transforma a faculdade da visão num olhar que enxerga sem ver, a domesticação do vizinho que passa banaliza a sua presença até torná-lo indiferente, e o pedestre acelera o passo sem mais interrompê-lo na parada no café ao ar livre, posto que isso agora seria correr um risco. Não é a toa que a questão da segurança está cada dia mais em pauta, desalojando o pedestre da rua e transpondo-o para "guetos voluntários", como são os condomínios cercados de muros e com guardas 24 horas por dia, onde a lógica funda-se na vigilância e na distância (Bauman, 2009, p. 39). E assim, "paradoxalmente, as cidades - que na origem foram construídas para dar segurança a todos seus habitantes - hoje estão cada vez mais associadas ao perigo" (Bauman, 2009, p. 40).

O resultado disso é o retorno ao temor que o habitante nutria pela cidade e que teve que ser apaziguado pelos fisiologistas de Paris, conforme vimos com Benjamin. Pode-se dizer que da fisiologia passa-se à mixofobia que, conforme Bauman (2009, p. 43), é o medo de misturar-se. "Essa mixofobia não passa da difusa e muito previsível reação à impressionante e exasperadora variedade de tipos humanos e de estilos de vida que se podem encontrar nas ruas das cidades contemporâneas e mesmo na mais 'comum' (ou seja, não protegida por espaços vedados) das zonas residenciais" (Bauman, 2009, p. 43).

Se havia uma predisposição do fisiologista a tornar o estranho familiar, pode-se dizer que o princípio da mixofobia é manter o outro à distância. Se havia uma intenção do fisiologista em absorver a diferença, dissecando-a, pode-se dizer que a mixofobia mais do que a ignora, repele-a. "A mixofobia se manifesta como impulso em direção a ilhas de identidade e de semelhança espalhadas no grande mar da variedade e da diferença" (Bauman, 2009, p. 44).

O problema, segundo Bauman (2009, p. 47), é que quanto maior e mais heterogênea for uma cidade, maiores são os atrativos que podem oferecer, e cria-se, assim, uma experiência ambivalente: se de um lado a variedade do ambiente urbano gera medo, por outro, esse mesmo "brilho caleidoscópio da cena urbana" seduz. Talvez este tenha sido o mesmo impasse vivido na cena urbana da Paris descrita por Benjamin no começo do século XIX e que fez com que, apesar do medo, os habitantes da grande cidade transpusessem o conforto e a segurança do lar burguês para se aventurar na imprevisibilidade da rua. E se a via de acesso à cidade tinha como limiar a porta das residências, hoje ela é substituída, conforme Virilio (1993, p. 9), pela "superfície-limite" da "interface". "É interessante, portanto, abordar a questão do acesso à Cidade de uma nova forma: a aglomeração metropolitana possuiu uma fachada? Em que momento a cidade nos faz face?" (Virilio, 1993, p. 9). Segundo Virilio, o espaço urbano perde 
cada vez mais sua realidade geopolítica em benefício dos sistemas tecnológicos instantâneos de deportação (de pessoas pelo remanejamento da produção, da atenção, do face a face humano, do contato urbano para a interface homemmáquina), a tal ponto que o autor se pergunta "se o que insistimos em chamar de ESPAÇO não seria tão-somente a LUZ, uma luz subliminar, para-óptica, em relação à qual o brilho do sol seria apenas uma fase, um reflexo, e isto em uma duração cujo padrão seria menos o tempo que passa da história e da cronologia do que o tempo que se expõe instantaneamente" (Virilio, 1993, p. 49). E assim, "à antiga ocultação público-privado e à diferenciação da moradia e da circulação sucede-se uma superexposição onde termina a separação entre o próximo e o distante" (Virilio, 1993, p. 10).

Na primeira transposição da porta que separava o espaço privado do público os citadinos contaram com a ajuda do jornalista (na pele do fisiologista, do flâneur ou do cronista). Caberia a esse profissional ajudar o sujeito moderno a se adaptar à aceleração, às rotinas de trabalho, à fragmentação do olhar, ao vizinho ameaçador, experiências essas vivenciadas de forma inédita na grande cidade. Caberia a ele procurar desvendar e compreender como

a experiência de viver nas grandes cidades modernas, planejadas em função dos novos fluxos energéticos e marcadas pela onipresença das novas técnicas, influencia e altera drasticamente a sensibilidade e os estados de disposição de seus habitantes (Sevcenko, 1998, p. 522).

Caberia a ele dar conta das várias encenações e notícias que ocorriam concomitantemente e de maneira cada vez mais veloz no palco da cidade, a tal ponto que Machado de Assis, em crônica de 1892 sobre o atropelamento de um pedestre por um bonde, apontaria um princípio de angústia no profissional escalado para acompanhar o novo ritmo dos acontecimentos:

Os acontecimentos parecem-se com os homens. São melindrosos, ambiciosos, impacientes, o mais pífio quer aparecer antes do mais idôneo, atropelam tudo, sem justiça nem modéstia... E quando todos são graves? Então é que é ver um miserável cronista, sem saber em qual pegue primeiro. Se vai ao que lhe parece mais grave de todos, ouve clamar outro que lhe não parece menos grave, e hesita, escolhe, torna a escolher, larga, pega, começa e recomeça, acaba e não acaba (Gledson, 1996, p. 160). 
Machado de Assis jamais poderia supor que a impaciência aludida por ele em 1892 atingiria o seu extremo hoje, na busca frenética pela notícia em tempo real e na sua divulgação instantânea no espaço cibernético, e que o atropelamento mencionado por ele teria como vítima mais grave o próprio jornalista. Aquele que precisa produzir velocidade, suprimir a duração, em suma, matar o tempo e ganhar mais espaço simultaneamente ${ }^{5}$.

E assim matar o tempo e o espaço converte-se na condição fundamental para a realização da atividade profissional do jornalista. Se há poucos anos profissionais como Ricardo Kotscho (1986) preconizavam que lugar de repórter era na rua, hoje o jornalista "bate em retirada". Se, como vimos, jornalistas pioneiros transpuseram a porta que dá acesso à cidade para se embrenhar num mundo de aventuras que só o espaço público fornecia, hoje, na cidade sem portas, convertem-se em interlocutores em trânsito permanente. Ou talvez nem em "trânsito", uma vez que a ausência de deslocamento também condiciona a economia de tempo. Antes mesmo do advento da Internet e de outros aplicativos de comunicação instantânea, Virilio (1993, p. 14) já reclamava de "um urbanismo sem urbanidade em que o tato e o contato cedem lugar ao impacto televisual".

[...] não somente a 'teleconferência', que permite comunicações à distância, com o progresso inerente à ausência de deslocamento, mas também a 'telenegociação' que permite, ao contrário, tomar distância, discutir sem se encontrar com seus parceiros sociais, onde existiria no entanto uma proximidade física imediata, em uma situação de certa forma semelhante à dos maníacos do telefone, para os quais a situação favorece o desvio da linguagem, o anonimato de uma agressividade telecomandada (Virilio, 1993, p. 14).

Ainda para o autor, esta substituição da observação direta dos fenômenos por uma "teleobservação" é arriscada, uma vez que "a ausência de percepção imediata da realidade concreta engendra um desequilíbrio perigoso entre o

5 Uma pesquisa recente feita pelo psicólogo, professor e pesquisador da Faculdade de Educação da Unicamp e da Fundação Getúlio Vargas, Roberto Heloani, revela por que os jornalistas estão adoecendo como nunca. Os Acidentes Vasculares Cerebrais (AVCs), o fenômeno da morte súbita, o aumento da dependência química, a síndrome do pânico, a depressão, os suicídios aumentaram assustadoramente na profissão. $80 \%$ dos profissionais pesquisados têm estresse e $24,4 \%$ estão na fase da exaustão, o que significa que de cada quatro jornalistas, um está sofrendo por conta da enorme carga emocional e física causada pelo trabalho. Tais considerações foram extraídas do artigo de Elaine Tavares, publicado em 24 de agosto de 2010, no Observatório da Imprensa. 
sensível e o inteligível, que só pode provocar erros de interpretação" (Virilio, 1993, p. 23).

Assim, se na cidade murada, portais, muros, pórticos delimitavam a cidade, na cidade contemporânea

a porta é aquilo que transporta veículos, vetores diversos cujas rupturas de continuidade compõem menos um espaço do que uma espécie de contagem regressiva em que a urgência do tempo de trabalho aparece como centro do tempo e o tempo livre das férias, do desemprego, como tempo de uma periferia, subúrbio do tempo, aplainamento das atividades no qual cada um é exilado em uma vida privada, em todos os sentidos do termo (Virilio, 1993, p. 11).

O mesmo exílio que vivenciavam os burgueses de Paris do século XIX antes de se aventurarem a transpor a porta da casa? Se nesse período, como bem observou Benjamin, o escritório era o centro de gravidade do espaço existencial do burguês, com o advento da "informática empresarial", conforme definiu Virilio (1993), ligada ao progresso da "teleinformática" (nota-se que o autor ainda não chegara à realidade das redes sociais), o "novo escritório" não é mais o cômodo à parte, mas uma simples tela, o terminal de um "escritório-visor" (Virilio, 1993, p. 58). Nele, as três dimensões do espaço seriam trocadas pelas duas dimensões de uma tela (de uma interface) que substituiria não só antigo cômodo (com sua mobília, seus documentos e planos de trabalho), mas que também economizaria o tempo de deslocamento de seu ocupante. Desta forma, além da reorganização do espaço construído (urbano e arquitetural), haveria uma redução dos espaços dos escritórios tradicionais e um reagrupamento de funcionários em atividades não centradas, resultando numa diminuição de custos para as empresas ${ }^{6}$.

Antunes (2009, p. 237) também preconiza, dentre as novas morfologias do trabalho, a expansão do trabalho a domicílio em várias partes do mundo, resultado da desconcentração do processo produtivo, do crescimento das pequenas e médias unidades produtivas, da telemática e das tecnologias de informação, além do avanço das formas de flexibilização e precarização do trabalho. E denuncia que o trabalho produtivo a domicílio acaba por se mesclar com o trabalho reprodutivo doméstico, aumentando as formas de exploração do contingente, sobretudo, feminino. Aliás, critica também que a tão propalada flexibilização pode ser entendida como “liberdade da empresa” para:

6 Para a redução de custos, surge também o espaço denominado coworking, modelo de trabalho em que profissionais que não necessariamente trabalham para a mesma empresa ou na mesma área de atuação alugam e compartilham o espaço e os recursos de escritório. 
desempregar trabalhadores sem penalidades, quando a produção e as vendas diminuem; reduzir ou aumentar as horas de trabalho; pagar salários mais baixos do que deveria; subdividir a jornada de trabalho segundo a sua conveniência; entre outras formas de precarização (Antunes, 2009, p. 234).

O trabalho à distância, abordado por Virilio (1993) a cerca das experiências francesas, em 1980, e por Antunes, já no século XXI, pode ser verificada, e atualizada, na reorganização do mundo do trabalho jornalístico. Se a antiga escrivaninha do escritório burguês deu lugar à tela do computador, no novo conceito de home-office, as gavetas virtuais do computador cedem lugar à "nuvem". O conceito de "computação em nuvem" (cloud computing) refere-se à utilização de computadores e servidores compartilhados e interligados por meio da Internet, podendo os dados, ser acessados de qualquer lugar do mundo, a qualquer hora. E assim, o mobiliário sólido e pesado do passado volatiza-se no espaço até atingir a forma metafórica de uma nuvem cuja aproximação no tempo pressupõe sempre um afastamento no espaço. E o espaço real das ruas, do traçado urbano, das relações de vizinhança, da encenação da vida, dos hábitos e fazes mundanos, tão caros aos fisiologistas, flâneurs ou cronistas (nossos jornalistas pioneiros) esvazia-se, "como se o 'povoamento do tempo' das telecomunicações (liberação de linhas, interrupção...) substituísse subitamente o das antigas coabitações, o povoamento do espaço, a proximidade urbana real" (Virilio, 1993, p. 61). E a polis, que havia emprestado sua etimologia à palavra política, dissipa-se até "não ser nada mais do que uma lembrança, uma rememoração da unidade de vizinhança, unidade esta que vem sofrendo continuamente os efeitos da mutação dos meios de comunicação de massa" (Virilio, 1993, p. 22). Ou não estariam os meios de comunicação apenas estampando a crise do tempo e do espaço encenados no palco da cidade?

\section{Considerações finais}

Procuramos neste artigo desvelar o quanto as novas configurações do tempo (cada vez mais acelerado) e do espaço (cada vez mais volátil) engendraram novas morfologias na prática laboral do jornalista, como a expansão do trabalho a domicílio (home-office), a prática do compartilhamento do escritório (coworking), a flexibilização e a instabilidade no trabalho. A partir de uma revisão bibliográfica sobre a temática e de entrevistas realizadas com profissionais da área, partimos da hipótese de que tais mudanças na forma como o jornalista se relaciona com o espaço, encurtando cada vez mais o tempo, na captação de informações que a cidade produz, repercutiriam na sua saúde e na sua vida mental, causando a precarização do seu ofício. Trazemos à luz algumas 
doenças que, infelizmente, tornam-se cada vez mais comuns no métier, como os Acidentes Vasculares Cerebrais (AVCs), o fenômeno da morte súbita, o aumento da dependência química, a síndrome do pânico, a depressão, os suicídios etc.

A partir de três passagens alegóricas destas (i)mobilidades no espaço partilhado da urbe - da casa à rua, da rua ao gabinete e do gabinete e da rua novamente a casa - todo um percurso que vai do encantamento ao desencantamento com o ofício e com a "musa urbana"(João do Rio, 2011). Do sentido orgânico da caminhada dos primeiros flâneurs ao olhar de passagem de quem acelera o tempo para suprimir o espaço, não mais na cinestesia dos bondes ou dos trens, ou até mesmo da fotografia ou do cinema, mas na tela vertiginosa dos tablets, iphones, computadores portáteis que se deslocam à medida do nosso deslocamento, a necessidade de substituir em alta velocidade a realidade em si pela virtual. Do gabinete rígido do passado, de mobiliário de madeira e cores frias, ao escritório multiplataforma convergente, cuja mesa central de comando, o "coração da redação", é a Internet, a rua se perde. Das grandes janelas ou terraços dos quais o jornalista contemplava a vida "lá fora" às telas que se espalham pela redação e trazem o mundo distante para perto, a rua se perde. Da casa acolhedora, "corpo de imagens que dão ao homem razões ou ilusões de estabilidade", como a definiu Bachelard (1988, p. 36), ao home-office que traz o escritório para dentro do lar, a jornada de trabalho incha e o ambiente doméstico não disfarça a pressão por resultados. $E$ a rua ainda se perde. Da experimentação orgânica da rua pelos primeiros cronistas ao jornalista multifunção, cuja experimentação do espaço se dá apenas pela tela "supersônica", algo indubitavelmente se perde.

Como conclusão preliminar, e a partir da análise destes três deslocamentos significativos no tempo e no espaço, encontramos as marcas do que muda e do que se mantém nos modos de vida e nas expressões do jornalista de ontem e de hoje. Desvelamos como a nova configuração volátil do espaço - além de remodelarem o lugar (o não lugar que ocupa a desocupação da cidade, a reconfiguração do antigo escritório num home-office) e o tempo (a aceleração, o tempo contínuo, a ubiquidade) do labor jornalístico - afetam o corpo e a vida mental daquele que o exerce. E o quanto o espaço-velocidade sem dimensão da interface virtual estaria desalojando o jornalista daquele que a princípio era sua razão de ser: o lugar partilhado da rua.

Afinal, "é nos lugares que se forma a experiência humana, que ela se acumula, é compartilhada, e que seu sentido é elaborado, assimilado e negociado. E é nos lugares, e graças aos lugares, que os desejos se desenvolvem, ganham forma, alimentados pela esperança de realizar-se" (Bauman, 2009, p. 35). 
Assim, são nos lugares partilhados da rua que se estabelecem a reflexão e o diálogo entre iguais ou estrangeiros, entre quem ameaça ou quem seduz.

\section{REFERÊNCIAS}

ANTUNES, Ricardo. "Século XXI: nova era da precarização estrutural do trabalho?" In: ANTUNES, Ricardo ; BRAGA, Ruy. (orgs.) Infoproletários: degradação real do trabalho virtual. São Paulo: Boitempo, 2009, p. 231-238.

BACHELARD, Gaston. A poética do espaço. São Paulo: Martins Fontes, 1988.

BARRETO, Lima. Recordações do escrivão Isaías Caminha. São Paulo: Ática, 2001.

BAUMAN, Zygmunt. Confiança e medo na cidade. Rio de Janeiro: Jorge Zahar, 2009.

O mal-estar da pós-modernidade. Rio de Janeiro: Jorge Zahar Ed., 1998.

BENJAMIN, Walter. Charles Baudelaire: um lírico no auge do capitalismo. São Paulo: Brasiliense, 1994a.

Rua de mão única: obras escolhidas volume II. São Paulo: Brasiliense, 1994b.

COUTINHO, Afrânio (org.). Machado de Assis: Obra Completa. Rio de Janeiro: Aguilar, 1959.

DUBY, Georges. História da Vida Privada 2: da Europa Feudal à Renascença. São Paulo: Companhia das Letras, 2009.

FIDALGO, Joaquim. Notas sobre "O lugar da Ética e da Auto Regulação na Identidade Profissional dos Jornalistas". Revista Comunicação e Sociedade, Minho, v.11, p. 37-56, 2007.

FONSECA, Juliane Figueiredo. A contribuição da ergonomia ambiental na composição cromática dos ambientes construídos de locais de trabalho de escritório. 2004. 292f. Dissertação (Mestrado em Design) - Pontifícia Universidade Católica do Rio de Janeiro (PUC), Rio de Janeiro, 2004.

FREUD, Sigmund. "O mal-estar na civilização (1930[1929])". In: Edição standard brasileira das obras completas de Sigmund Freud. Rio de Janeiro: Imago, v. XXI, p. 110-11, 1974.

GLEDSON, John. Bons Dias! Crônicas (1888-1889) Machado de Assis. São Paulo: Hucitec, 1996.

JOÃO DO RIO. A alma encantadora das ruas. São Paulo: Companhia de Bolso, 2011.

KOTSCHO, Ricardo. A prática da reportagem. São Paulo: Ática, 1986. 
MORIN, Edgar. Cultura de Massas no Século XX: o Espírito do Tempo - 2: necrose. Rio de Janeiro: Forense-Universitária, 1977.

MOROZOV, Evgeny.A segunda morte do flâneur: o facebook está matando a ideia de flanar pela internet. O Estadão (09/02/2012): São Paulo. Disponível em: <http:// www.estadao.com.br>. Acesso em: 12 nov. 2014.

NEEDELL, Jeffrey D. Belle époque tropical: sociedade e cultura de elite no Rio de Janeiro na virada do século. São Paulo: Companhia das Letras, 1993.

SALAVERRÍA, Ramón; NEGREDO, Samuel. Periodismo integrado: convergência de medios y reorganización de redacciones. Barcelona: Editorial Sol90, 2008.

SALAVERRÍA, Ramón. Diezaños de logros y retos en la prensa digital. Revista Comunicação e Sociedade, Minho, v. 9, n. 10, p. 129-137, 2006.

SANTOS, Jeana. Narrativas sobre a cidade: entre o medo e o fascínio. Revista Comunicação, Mídia e Consumo. São Paulo, v. 11, n. 31, p. 83-98, maio/ago 2014.

. Experiências pioneiras de Machado de Assis sobre o jornal. 2002. $261 \mathrm{f}$. Tese (Doutorado em Literatura) - Programa de Pós-Graduação em Literatura, UFSC, Florianópolis, 2002.

SEVCENKO, Nicolau (org.). História da vida privada no Brasil República: da Belle Époque à Era do Rádio. São Paulo: Companhiadas Letras, 1998.

TAVARES, Elaine. Por que os jornalistas estão adoecendo mais. Observatório de Imprensa, 24 ago. 2010. Disponível em: $\leq$ http://www.observatoriodaimprensa. com.br>. Acesso em: 22 out. 2013.

TOZZI, Elisa. Escritório: história de produtividade, desconforto e poder. Revista Você S/A, 26 jun. 2014. Disponível em: <http://exame.abril.com.br/revista-voce-sa>. Acesso em: 3 mar. 2015.

VIRILIO, Paul. O espaço crítico e as perspectivas do tempo real. Rio de Janeiro: Ed. 34, 1993. 